Journal of Social and Development Sciences

Vol. 3, No. 10, pp. 331-334, Oct 2012 (ISSN 2221-1152)

\title{
Competency Strategies in Alleviating Poverty for Sustainable Development in the Teaching and Learning of Home Economics Education
}

\author{
Obasigie, I. O, Omoregbe, I. I \\ College Of Education, Ekiadolor, Benin City, Nigeria
}

\begin{abstract}
This study looked at poverty scenario in Edo State and how Home Economics graduate from the universities can use their competency to alleviate poverty for sustainable development. A self-developed questionnaire of 4 point instrument was used for data collection from 150 respondents from 25 shops in 2 zones i .e commercial and residential areas in Edo State. The data collected was subjected to frequency distribution count and percentage rating analysis. The findings shows that majority of the home economics graduate from our universities exhibited low competencies of less than $15.0 \%$ in business management feasibility, business risk management, business finance management, and creativity ability in alleviating poverty in their chosen business ventures: the reasons being that they were all involved in buying and selling cake items for baking, interior decoration items, provision and toiletries among others. Findings further revealed that all the studied respondents were highly constrained by lack of competency strategies; solutions were thus proffered and established for sustainable development.
\end{abstract}

Keywords: Poverty, Home Economics, Competency, Sustainable development and Graduates

\section{Introduction}

Wide spread poverty and hunger is an enduring problem affecting an estimated 800 million people worldwide and it is a factor responsible for at least five million deaths each year in the developing countries (UNICEF, 2002). The focus of Home Economics Education is to equip individuals with relevant knowledge, skills and attitudes for work in chosen occupations and career opportunities. This type of education also emphasizes that after training, the trainee would be self employed and reliant thus producing goods and services as entrepreneurs for the benefits of the society. In 2004, the Federal Government of Nigeria in its national policy on education equivocally spelt out the broad aims and objectives of Home Economics Education under vocational and technical education to include "To give training and impact the necessary skills leading to the production of craftsmen, fashion designer, interior decorator, event planners and other skilled personnel who will be enterprising and self reliant." Osuala (2001) also advocated for greater emphasises on vocational Education (Home Economics Education) which has as its goal the "preparation of the learner for entry into employment and advancement in his chosen career, meeting the labor needs of the society, increasing the option available to students and adults and to enable learners to wisely select a career. Obasigie and Orumwense (2009) opined that when the human and natural resources of a nation are not sufficiently developed, poverty becomes the order of the day and the economic scene will be eluded with various problems to the extent that policy makers, practitioners and public will appear to be in a state of confusion. Poverty is not just lack of income or employment but also total deprivation of essentials hence it is defined as a state of non-fulfilment of minimum requirement of food, shelter and clothing, which are the component forms of economic, social and psychological deprivations. It is against this background that this article seeks to identify the competencies of Home Economics graduates in poverty alleviation, in Edo State with a view to proffering suggestions that could create sustainable development.

Purpose of Study: The major purpose of this study is to investigate the entrepreneurship competence by Home Economics graduate in alleviating poverty in Edo State. Specifically the study will determine Home Economics Education competencies in learners about:

- Competencies on business feasibility

- Business risk management

- Business finance management

- Competencies in creativity in business ventures 


\section{Methodology}

The design of the study is a survey research on the investigation of how Home Economics Education can alleviate poverty in a depressed economy like Edo State. According to Kerlinger (2004), survey research is a useful tool employed by researchers when they are interested in the opinions and attitudes of people as well as the relationship of their attitudes to the respondent's overt behaviour.

Population - The area of the study was Edo State in Nigeria. The population was made up of university graduates of Home Economics Education in the area of study. The entire population was studied. The respondents were all self-employed in 25 identified small scale enterprises zoned into two areas i.e. residential and commercial zones. The residential zone is made up of small scale businesses located in GRA and its environs and the commercial zone covers shops around the ever busy Ring Road i.e. Mission Road, Oba market road, Ekenhuan road and New Benin market.

Sample and Sampling Technique - A self developed questionnaire was used for data collection, it was validated by Home Economists expert before being used for data collection. A total of 300 samples were identified for the study and 75 small scale enterprises were randomly selected from each zone giving a total of 150 shops. The data collected using a 4 - point instrument of 7 items rating scale of highly possessed, fairly possessed and not possessed was developed based on the specific purposes of the study. The instruments were then subjected to percentage analysis.

Data Analysis Technique - In analyzing the data obtain from the study, frequency distribution and percentage rating were computed for each item on statements on competencies on business feasibility, risk management, financial management and creativity in the business venture of university graduates of Home Economics Education in Edo State Nigeria. A percentage of $15 \%$ and above for the 4- point rating was accepted as possessed while percentage scores less than $15 \%$ for any item was considered as not possessed for further clarification.

\section{Results}

Table 1: Statement on competencies on business feasibility study of Home Economics graduates from university

\begin{tabular}{llll}
\hline Competencies & Frequency & Percentage (\%) & Remarks \\
\hline Location of business site & 30 & 20.0 & Highly Possessed \\
Identifying potential buyers & 28 & 18.6 & Highly Possessed \\
Location of raw materials for business & 13 & 8.7 & Not possessed \\
Identification of business competitors & 19 & 12.7 & Not possessed \\
Identification of business personnel & 10 & 6.7 & Not possessed \\
Locating favourable business environment & 25 & 16.6 & Fairly Possessed \\
Identification of viable business venture & 25 & 16.6 & Fairly Possessed \\
Total & 150 & 100 & \\
\hline
\end{tabular}

Source: Researcher's Fieldwork, 2011

Statement on competencies on business feasibility possessed by university graduates of Home Economics Education shows that out of the 7 item identified, four(4) were rated as adequate competencies as their percentage was above $15.0 \%$, while three (3) were rated as not adequate, as their percentage rate falls below $15 \%$. This goes to show that some of the graduates do not possess the required business competencies in regards to feasibility study needed in their related career choice. This finding supports the work of Osuala (2001) that greater emphasis on vocational education will enable the learner to advance in his chosen career. 
Table 2: Statement on competencies on risk management by university graduates of home Economics

\begin{tabular}{llll}
\hline Risk management & Frequency & Percentage (\%) & Remarks \\
\hline $\begin{array}{l}\text { Coping with technological challenges } \\
\text { Management of mechanical and electrical }\end{array}$ & 24 & 16 & Fairly Possessed \\
breakdowns & 30 & 20.0 & Highly Possessed \\
$\begin{array}{l}\text { Coping with government inconsistent policies } \\
\text { relating to small scale business sector }\end{array}$ & 10 & 7.0 & Not Possessed \\
$\begin{array}{l}\text { Identification of quality control strategies } \\
\text { Coping with death of business partners }\end{array}$ & 16 & 11 & \\
Coping with price fluctuations in the market & 20 & 13 & Not possessed \\
$\begin{array}{l}\text { Identification of product seasonality } \\
\text { Total }\end{array}$ & 25 & 17 & Not Possessed \\
\hline
\end{tabular}

Source: Researcher's Fieldwork, 2011

Table 3: Financial management of university graduates of Home Economics Education

\begin{tabular}{llll}
\hline Competencies & Frequency & Percentage (\%) & Remarks \\
\hline $\begin{array}{l}\text { Identification of business capital (direct or } \\
\text { indirect source) }\end{array}$ & 45 & 30.0 & Highly Possessed \\
$\begin{array}{l}\text { Projection of profit margin } \\
\text { Book - keeping and Accounting }\end{array}$ & 18 & 12.0 & Not possessed \\
$\begin{array}{l}\text { Determination of depreciation of equipment and } \\
\text { structures }\end{array}$ & 10 & 7.0 & Not possessed \\
Product - price fixing & 12 & 8.0 & Not possessed \\
Sourcing for loan & 10 & 7.0 & Not possessed \\
Registration of business site & 43 & 28 & Highly Possessed \\
Total & 12 & 8.0 & Not possessed \\
\hline
\end{tabular}

Source: Researcher's Fieldwork, 2011

The statement aimed at identifying competencies in business risk management of university graduates of Home Economics Education shows that the respondents exhibits adequate competencies in four (4) out of the 7 items identified while the other three items lacks competencies in coping with business risk management. This is in line with the work of Obasigie and Orunmwese (2009) which says the economic scene in Nigeria is eluded with various problems to the extent that policy makers and the general public often appears to be in a state of confusion.

The statement on financial management of university graduates of Home Economics Education shows that out of the 7 items identified, only 2 items possessed the competencies for financial management while the remaining 5 lacks the adequate competencies in financial management. This goes to show that if graduate of Home Economics Education are not given adequate assistance in terms of finance, they may not be able to cope in running successful business venture.

Table 4: Creativity competencies of university graduates of Home Economics Education in business management

\begin{tabular}{llll}
\hline Competencies & Frequency & Percentage (\%) & Remarks \\
\hline Advertisement and marketing & 20 & 13.0 & Not Possessed \\
Satisfying customers needs & 31 & 21.0 & Highly Possessed \\
Coping with staff welfare obligation & 15 & 10.0 & Not Possessed \\
Identification of staff dispute & 16 & 11.0 & Not Possessed \\
Identification of alternative raw materials & 18 & 12.0 & Not Possessed \\
(improvisation) & & & \\
Organization of return on resources & 10 & 7.0 & Not Possessed \\
Mobile shops & 40 & 26.0 & Highly Possessed \\
Total & 150 & 100 & \\
\hline
\end{tabular}

Source: Researcher's Fieldwork, 2011 
The findings on creativity competencies of university graduates of Home Economics Education shows that majority of the respondents do not possess business management competencies while only 2 of the items shows creativity ability. This implies that vocational education program in our universities probably produce graduate who are not sufficiently skilled in their fields of study as they are deficient in creativity, innovation, risk taking and profit making activities which are dispensable to managerial ventures. In all the statistical analysis, it can be deduced that there is an increasing predominantly white collar jobs (civil service) economy, which is becoming highly saturated thus generating unemployment and underutilization of Nigeria's human and natural resources. The work of Ukwe (2007) is line with these findings when he declared that the culture of post independent Nigeria consciously created by the ruling class has been responsible for the level of domestic developmental stagnation in various vocations, characterized by the greed and insatiable crave for the national cake, thus disregarding resourcefulness and dignity of labour.

Recommendations: Based on the above findings and if the goals of Home Economics Education are to be achieved in alleviating poverty, the following recommendations are proffered -

- The students industrial work scheme (SIWES) should be properly implemented and enforced. Big industries and other small-scale enterprise should be put in place, along with the required infrastructural facilities that will enhance practical learning activities in the learner.

- The objectives of vocational education has spelt out by the federal government should be established in our universities so that the students interest will be aroused.

- Home Economics Education should be seen as Education for the coordinated and articulated minds and not Education for the underprivileged, maladjusted, the physically challenged among others.

- Vocational programmes in the university especially Home Economics Education should be reviewed to focus on entrepreneurship, creativity, resourcefulness and managerial skills.

- Soft loans should always be given to Home Economics student on graduation by banks and the government to enable them to establish small - scale enterprise to promote sustainable development in developing nations and poverty alleviation programs established by government for graduate of vocational Education should be earnestly sustained for technological advancement.

- Poverty alleviation programs such as National Directorate of Employment (NDE) and Lift above Poverty Organization (LAPO) established by government for graduate of vocational education should be earnestly pursued and implemented for sustainable technological development.

\section{Conclusion}

This study has identified various competencies possessed by Home Economics graduates from the Nigerian universities in relation to their ability to alleviate poverty in the Nigerian economy. The level of possession of the needed competencies in alleviating poverty was considered low and inadequate for the purpose of self reliance, as this is based on the fact that majority of the graduates studied where involved in the same type of business venture such as buying and selling cake items for baking, interior decoration items, children's clothing, provisions and toiletries among others in the same business location. This type of business on the long run is not sufficient in alleviating poverty in a depressed economy. Credence is therefore called for sustainable vocationalization of Home Economics curriculum to ensure that university graduates in the discipline are fully equipped to be a job creator rather than a job seeker thus disregarding the crave for white collar jobs and the national cake.

\section{References}

Federal Government of Nigeria. (2004). National Policy on Education. Revised Edition.

Kerlinger, F. (2004). Site Template designed by ELS, Kent NGFL, Oxford Road, Maidstine, MELSSAW.

Obasigie, I. O. \& Orumwense, F. E. (2009). Journal of Contemporary Issues in Vocational and Technical Education, 3(1).

Osuala, E. C. (2001). Principles and Practices of Small Businesses Management in Nigeria, Nsukka fullady comp. Ukwe, U. I. (2004). Towards Effective Poverty Eradication Strategies NCEMA.

UNICEF. (2002). Facts for Life: A Communication Challenge. Shire Oxford, England.

World Bank Report. (2001). Sub - Sahara Crisis to Sustainable Growth: A long Term Perspective Study. Washington D.C. 